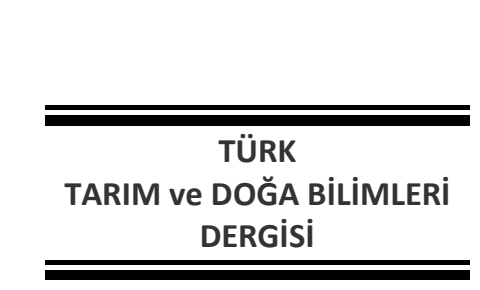

\section{.}

https://doi.org/10.30910/turkjans.557099

\title{
Doğadan Toplanan ve Kültürü Yapılan Pleurotus ostreatus ve Agaricus bisporus Mantarlarının Toplam Protein, Vitamin ve Yağ Asidi İçeriklerinin Belirlenmesi
}

\author{
Aydın Şükrü BENGÜ1*, Handan ÇINAR YILMAZ ${ }^{1}$, İbrahim TÜRKEKUL ${ }^{2}$, Hakan IŞIK \\ ${ }^{1}$ Bingöl Üniversitesi, Sağlık Hizmetleri Meslek Yüksekokulu, Tıbbi Hizmetler ve Teknikler Bölümü, Tıbbi Laboratuvar \\ Teknikleri Programı, Bingöl, Türkiye \\ ${ }^{2}$ Gaziosmanpaşa Üniversitesi, Fen Edebiyat Fakültesi, Biyoloji Bölümü, Tokat, Türkiye \\ ${ }^{3}$ Tokat Bilim ve Sanat Merkezi, Tokat, Türkiye \\ *Sorumlu yazar: abengu@bingol.edu.tr
}

Geliş Tarihi: 23.10.2018

Düzeltme Geliş Tarihi: 19.02.2019

Kabul Tarihi: 26.02 .2019

\section{Özet}

Bu çalışmada, kültür ortamında yetiştirilmiş ve doğadan toplanmış olan Pleurotus ostreatus (Jacq.) P. Kumm. ve Agaricus bisporus (J.E. Lange) Imbach mantarlarının toplam protein, vitamin ve yağ asidi bileşimleri, vitaminleri tespit edilmiş̧ir. Araştırma materyallerinde 11 çeşit yağ asidi (miristik asit, pentadekanoik asit, palmitik asit, palmitoleik asit, margarik asit, stearik asit, oleik asit, linoleik asit, eikosenoik asit, behenik asit, nervonik asit) belirlenmiş olup, bu yağ asidlerinin arasında linoleik asidin \%40.31-\%54.44 ile en yüksek içeriğe sahip olduğu bulunmuştur. Her iki türün doğadan toplanan örneklerinde toplam protein miktarlarının kültürü yapılanlara göre daha yüksek olduğu saptanmıştır. En yüksek $A$ ve E vitamini içeriği Agaricus bisporus türünün kültür ortamında yetiştirilmiş örneklerinde en yüksek $C$ vitamini içeriği ise Pleurotus ostreatus türünün doğadan toplanan örneklerinde tespit edilmiştir. Bu çalışmada kullanılan mantar örneklerinde doymamış yağ asidi miktarının doymuş yağ asidi miktarından daha fazla olduğu belirlenmiştir.

Anahtar kelimeler: Agaricus bisporus, yağ asitleri, gaz kromatografisi, mantar, Pleurotus ostreatus.

\section{Determination of Total Protein, Vitamin and Fatty Acid Content of Pleurotus ostreatus and Agaricus bisporus Mushrooms Collected from Nature and Cultured}

\begin{abstract}
In this study, fatty acid compositions, vitamins and total protein content of Pleurotus ostreatus (Jacq.) P. Kumm. and Agaricus bisporus (J.E. Lange) Imbach species grown in the culture medium and collected from the natural environment were determined. In research materials, 11 kinds of fatty acid (myristic acid, pentadecanoic acid, palmitic acid, palmitoleic acid, margaric acid, stearic acid, oleic acid, linoleic acid, eicosenoic acid, behenic acid, nervonic acid) were found, of which $40.31 \%$ - $54.44 \%$ Linoleic acid was found to be the most common. It was observed that the amount of total protein was higher in both species than the ones grown in culture. While the vitamin $A$ and E vitamin levels were found to be highest in the agaricus bisporus species cultivated in culture medium, it was found that vitamin C was higher in natural specimens of Pleurotus ostreatus species. In this study, the amount of unsaturated fatty acid was higher than the amount of saturated fatty acid in the mushroom samples.
\end{abstract}

Key words: Agaricus bisporus, fatty acids, gas chromatography, mushroom, Pleurotus ostreatus. 


\section{Giriş}

Mantarlar dünyada tür çeşitliliği en fazla olan canlılardan biridir. Dünya genelinde yayılış gösteren 1.5 milyon mantar türü olduğu tahmin edilse de, bunlardan ancak 70 bin türü literatürlerde yer almaktadır. Bu kaydedilen türler arasında 5020 yenir, 1250 yenmez, 1010 zehirli, 1820 tıbbi özellik gösteren olmak üzere toplamda 10 bin civarında makromantar bulunmaktadır (Hawksworth ve ark., 1996; Hawksworth, 2001; Pekşen, 2013). Kirk (2011)'e göre dünyada kaydedilen mantar sayısı 500 binin üzerindedir.

Doğal bitki örtüsüne sahip kırsal bölgelerde yaşayan halk için doğada yetişen mantarlar, önemli bir besin ve geçim kaynağıdır. Mantarların besin olmalarının yanısıra kanser, hiperkolesterolemi, hipertansiyon, stres, astım, insomnia, alerji, diyabet gibi çeşitli hastalıkların önlenmesinde önemli bir etkiye sahip olduğu da bilinmektedir. Yapılarında bulundurdukları yararlı kimyasal bileşikler ve biyolojik aktiviteleri nedeniyle tıp alanında kullanılmaktadırlar (Çağlarırmak 2011). Kolesterol ve kalori değerlerinin düşük olması, proteinler, vitaminler, mineraller, lif ve eser elementler açısından zengin olması yönüyle oldukça sağlıklı besinlerdir. Birçok yenilebilir mantar türünün yüksek düzeyde birkaç çeşit doymamış yağ asidi depoladığı bilinmektedir. Mantarların yapısında bulunan yağ asidini belirlemeye yönelik yapılan çalışmalarda başlıca yağ asitleri olarak linoleik asit ve oleik asit tespit edilmiştir (Yılmaz, 2006, Ergönül, 2013, Korkmaz, 2014, Woldegiorgis, 2015, Goyal ve ark., 2015, Doğan, 2016, Yılmaz ve Bengü, 2018). Yine Cordyceps sinensis ile yapılan çalışmalarda toplam yağ asidi miktarının \%27.4' nün çoklu doymamış yağ asitlerinden oluştuğu tespit edilmiştir (Ergönül, 2013). Mantarlar, hayvansal proteinlere benzer aminoasit bileşimine sahiptir. $\mathrm{Bu}$ açıdan et, süt, yumurta ile kıyaslanabilir. Doğal olarak yetişen mantarlar, kültür ortamda yetiştirilmiş mantarlara kıyasla, zengin protein kaynağı ve daha az yağ oranı bulundurur (Ergönül ve ark., 2013; Goyal ve ark., 2015; Ganesh ve ark., 2017).

Mantarlar doğal ortamından toplanabileceği gibi daha çok kültür mantarı şeklinde tüketim tercih edilmektedir (Kibar, 2015). 2013 yılı verilerine göre dünyada toplam mantar üretimi 10 milyon ton civarındadır. Mantar üretimi yapan ülkeler içerisinde Çin en fazla mantar üreten ülkedir ve mantar ihtiyacının \%80'nini karşılamaktadır. Dünyada kültürü yapılan mantarlar içerisinde Agaricus cinsi (\%30), Pleurotus cinsi (\%27), Lentinula cinsi (\%17) ilk üç sırayı almaktadır ve kültürü yapılıp tüketilen mantarların yaklaşık \%74'ünü oluşturmaktadır. Türkiye'de kültürü yapılan mantarlarda ilk üç grup, Agaricus (\%86), Pleurotus (\%10) ve Lentinula edodes (\%3) şeklindedir. Son yıllarda Ganoderma lucidum ve Hericium erinaceum mantarları az oranda da olsa üretilmeye başlanmıştır (Zhang ve ark., 2014; Kibar, 2015; Eren ve Pekşen, 2016).

$\mathrm{Bu}$ çalışmanın amacl; doğadan toplanan ve kültür ortamında yetiştirilen Pleurotus ostreatus ve Agaricus bisporus mantarlarının doymuş, tekli doymamış ve çoklu doymamış yağ asidi profilleri, vitamin ve toplam protein seviyelerini belirlemektir.

\section{Materyal ve Yöntem}

Doğadan toplanan Pleurotus ostreatus ve Agaricus bisporus mantar örnekleri Tokat ilinin değişik lokalitelerinden toplanmıştır. Kültür ortamında yetiştirilen mantar örnekleri ise Gaziosmanpaşa Üniversitesi Biyoloji bölümünden temin edilmiştir. Laboratuvar ortamında kurutulan mantar örnekleri parçalayıcı yardımıyla toz haline getirilmiş ve daha sonraki çalışmalar için plastik kaplara konulmuştur.

Kurutulmuş mantar örneklerinden lipit ekstraksiyonu için Hara ve Radin (1978) metodu, metil esterlerinin elde edilmesi için Christie (1990) metodu revize edilerek kullanılmıştır. Bunun için 5 gr kuru mantar örneği homojenizatörde 10.000 rpm'de 30 saniye ile $10 \mathrm{~mL}$ hekzan/izopropanol (3:2) içerisinde parçalanmış ve 5000 rpm'de 10 dakika santrifüj edilmiştir. Üst kısım alınıp, süzülerek deney tüplerine konulmuştur. Metil esteri hazırlamak için, lipit ekstraktı $30 \mathrm{~mL}$ kapaklı tüplere alınmıştır. Üzerine \%2'lik metanolik sülfirik asitten $5 \mathrm{~mL}$ eklenip vortekslenmiştir. Bu karışım $50{ }^{\circ} \mathrm{C}$ lik etüvde 15 saat metillenmesi için bekletilmiştir. 15 saat sonunda tüpler çıkarılarak oda sıcaklığına kadar soğutulmuş ve $5 \mathrm{~mL} \% 5^{\prime}$ lik $\mathrm{NaCl}$ eklenerek vortekslenmiştir. Tüpler içinde oluşan yağ asitlerinin metil esterleri (FAME), $5 \mathrm{~mL}$ hekzan ile ekstre edilmiştir. Daha sonra hekzan fazı üstten pastör pipeti ile alınarak $5 \mathrm{~mL} \% 2^{\prime}$ lik $\mathrm{KHCO}_{3}$ ile muamele edildi ve fazların ayrılması için 1-2 saat beklenmiştir. Metil esterlerini ihtiva eden karışımın çözücüsü $45^{\circ} \mathrm{C}^{\prime}$ de azot altında uçurulmuştur. Deney tüplerinin altındaki yağ asidleri $1 \mathrm{~mL}$ hekzan ile çözülerek ağzı kapaklı koyu renk GC vialllerine alınarak GC-MS cihazında analiz edilmiştir.

Çalışmamızda Agilent marka 7890A/5970C model GC-MS cihazı (USA) ve SGE Analytical BPX90 (100m x $0.25 \mathrm{~mm} \times 0.25$ um kolon) (Australia) kullanılmıştır. Sıcaklık toplam 45 dakika içerisinde $120{ }^{\circ} \mathrm{C}^{\prime}$ den başlayarak $250{ }^{\circ} \mathrm{C}^{\prime}$ ye kadar kademeli olarak yükseltilmiş ve analiz süresince bu sıcaklıkta bekletilmiştir. Örneklerin analizinde taşıyıcı gaz He olarak seçilmiştir. Standart yağ asidi numuneleriyle 
sistemin kalibrasyonu yapılmış ve örneklerdeki doğal yağ asitleri tespit edilmiştir.

Örneklerin vitamin içeriklerinin tespitinde ters faz HPLC metodu kullanılmıştır (Alayunt ve ark., 2015, Çöteli ve Karataş 2015). Bu metotta; $0.3 \mathrm{~g}$ mantar alınarak $4 \mathrm{~mL}$ etil alkol (\%1 $\mathrm{H}_{2} \mathrm{SO}_{4}$ içeren) de çözülür, proteinler parçalanır. Örnekler 4500 rpm'de 25 dakika santrifüj edilerek $0.3 \mathrm{~mL}$ hekzan eklenir ve iyice vortekslenir ve tekrar santrifüjlenir. Santrifüjden sonra hekzan karışımı dikkatlice cam tüpe alınır ve $0.3 \mathrm{~mL}$ hekzan eklenerek tekrar santrifüjlenir. Hekzan azot altında uçurulur ve 1000 $\mu \mathrm{L}$ metanol ile çözülür ve $20 \mu \mathrm{L}$ HPLC ye enjekte edilir. A vitamini $326 \mathrm{~nm}^{\prime}$ de, E vitamini $296 \mathrm{~nm}$ 'de C vitamini de $245 \mathrm{~nm}$ 'de dedekte edilmiştir. Tüm örnekler standart grafiğe karşı 3 kez okunup ortalaması alınmıştır.

Toplam protein seviyelerinin tespitinde Dumas metodu kullanılmıştır. Gerhardt marka Dumaterm model (made in Germany) cihaz kulanılarak homojenize edilen mantar örnekleri ince elekten geçirilmiş ve yaklaşık $50 \mathrm{mg}$ tartılmıştır. Cihaza özel tin foil içerisine alınarak cihazın yakma ünitesine atılmış, burada $\mathrm{O}_{2}$ ile $1200{ }^{\circ} \mathrm{C}^{\prime}$ de yakılmıştır, gaz fazına geçen bileşikler çeşitli filtrelerde tutulmuştur, He tarafından taşınan $\mathrm{N}_{2}$ termal iletkenlik dedektörü tarafından ölçülmüştür. Tespit edilen $\% \mathrm{~N}_{2}$ miktarı, 6.25 olan protein faktörü ile çarpılarak örnekteki \% protein miktarı kantitatif olarak tespit edilmiştir.

\section{Bulgular ve Tartışma}

Doğadan toplanan ve kültür ortamından yetiştirilen Pleurotus ostreatus ve Agaricus bisporus mantarlarının yağ asidi profili, yağ asitlerinin metil esterleri elde edildikten sonra gaz kromotografisi yöntemi kullanılarak belirlenmiştir. Araştırmalar sonucunda doymuş (myristik asit, pentadekanoik asit, palmitik asit, margarik asit, stearik asit, eikosenoik asit, behenik asit), tekli doymamış (palmitoleik asit, oleik asit, eikosenoik asit, nervonik asit) ve çoklu doymamış yağ asitleri (linoleik asit) elde edilmiştir. Bu yağ asitleri ve yüzde oranları Çizelge 1'de bunların toplam yüzde oranları Çizelge 2'de gösterilmiştir.

Çizelge 1. Doğadan toplanan ve kültürü yapılan Agaricus bisporus ve Pleurotus ostreatus mantarlarının yağ asidi profilleri (\%)

\begin{tabular}{lcccc}
\hline Yağ asidi çeşidi & $\begin{array}{c}\text { Pleurotus } \\
\text { ostreatus (kültür) }\end{array}$ & $\begin{array}{c}\text { Pleurotus } \\
\text { ostreatus (doğal) }\end{array}$ & $\begin{array}{c}\text { Agaricus } \\
\text { bisporus (kültür) }\end{array}$ & $\begin{array}{c}\text { Agaricus } \\
\text { bisporus (doğal) }\end{array}$ \\
\hline Myristik asit (C14:0) & 1.16 & - & 1.00 & 0.96 \\
Pentadekanoik asit (C15:0) & 5.15 & 6.18 & 3.65 & 3.54 \\
Palmitik asit (C16:0) & 21.09 & 20.54 & 18.45 & 20.97 \\
Palmitoleik asit (C16:1) & - & 4.34 & 3.43 & - \\
Margarik asit (C17:0) & - & - & - & 3.58 \\
Stearik asit (C18:0) & 14.35 & 16.05 & 14.71 & 11.61 \\
Oleik asit (C18:1) & 17.90 & 12.57 & 4.33 & 3.46 \\
Linoleik asit (C18:2) & 40.35 & 40.31 & 54.44 & 49.74 \\
Eikosenoik asit (C20:1) & - & - & - & 0.56 \\
Behenik asit (C22:0) & - & - & - & 5.58 \\
Nervonik asit (C24:1) & 5.01 & 7.22 & - & - \\
\hline
\end{tabular}

Çizelge 2. Doymuş, tekli doymamış ve çoklu doymamış yağ asitlerinin oranı (\%)

\begin{tabular}{lcccc}
\hline Yağ asidi çeşidi & $\begin{array}{c}\text { Pleurotus } \\
\text { ostreatus } \\
\text { (kültür) }\end{array}$ & $\begin{array}{c}\text { Pleurotus } \\
\text { ostreatus } \\
\text { (doğal) }\end{array}$ & $\begin{array}{c}\text { Agaricus } \\
\text { bisporus } \\
\text { (kültür) }\end{array}$ & $\begin{array}{c}\text { Agaricus } \\
\text { bisporus } \\
\text { (doğal) }\end{array}$ \\
\hline Toplam yağ asidi & 105.01 & 107.21 & 100.01 & 100 \\
Toplam doymuş yağ asidi & 41.75 & 42.77 & 37.81 & 46.24 \\
Toplam doymamış yağ asidi & 63.26 & 64.44 & 62.2 & 53.76 \\
Toplam tekli doymamış yağ asidi & 22.91 & 24.13 & 7.76 & 4.02 \\
Toplam çoklu doymamış yağ asidi & 40.35 & 40.31 & 54.44 & 49.74 \\
\hline
\end{tabular}

Pleurotus ostreatus ve Agaricus bisporus türlerinin örneklerindeki toplam protein içerikleri bakımından doğa mantarı örneklerinin kültüre edilmiş örneklere göre daha yüksek oranda olduğu ve her iki türde de birbirine benzer olduğu tespit edilmiştir (Çizelge 3). Turfan ve ark. (2018) doğada yetişen mantarların toplam çözünebilir protein, toplam fenolik, toplam flavonoid, potasyum, fosfor, kükürt, klor, sodyum, demir, kalsiyum, manganez, selenyum, çinko ve bakır içeriklerinin kültürü 
yapılan mantarlardan daha yüksek olduğunu bildirmişlerdir.

Çalışmada A vitamininin Agaricus bisporus türünde Pleurotus ostreatus türüne göre daha yüksek miktarlarda bulunduğu tespit edilmiştir. E vitamini miktarının ise Pleurotus türünün doğadan toplananlarında, Agaricus türünün kültür ortamında yetiştirilen mantarlarda daha yüksek olduğu belirlenmiştir. C vitamininin ise her iki türün doğadan toplanan örneklerinde daha yüksek olduğu bulunmuştur (Çizelge 4).

Çizelge 3. Doğadan toplanan ve kültürü yapılan Agaricus bisporus ve Pleurotus ostreatus mantarlarının toplam protein miktarları (\%)

\begin{tabular}{lc}
\hline Mantar örnekleri & $\begin{array}{c}\text { Toplam protein } \\
\text { (\%) }\end{array}$ \\
\hline Pleurotus ostreatus (kültür) & 22.04 \\
Pleurotus ostreatus (doğal) & 34.19 \\
Agaricus bisporus (kültür) & 22.22 \\
Agaricus bisporus (doğal) & 35.17 \\
\hline
\end{tabular}

Çizelge 4. Doğadan toplanan ve kültürü yapılan Agaricus bisporus ve Pleurotus ostreatus mantarlarının vitamin içerikleri $(\mu \mathrm{g} / \mathrm{g})$

\begin{tabular}{lccc}
\hline $\begin{array}{l}\text { Mantar } \\
\text { örnekleri }\end{array}$ & $\begin{array}{c}\text { A } \\
\text { vitamini }\end{array}$ & $\begin{array}{c}\text { E } \\
\text { vitamini }\end{array}$ & $\begin{array}{c}\text { C } \\
\text { vitamini }\end{array}$ \\
\hline $\begin{array}{l}\text { Pleurotus } \\
\text { ostreatus } \\
\text { (kültür) }\end{array}$ & 73.38 & 763.32 & 352.60 \\
$\begin{array}{l}\text { Pleurotus } \\
\text { ostreatus } \\
\text { (doğal) }\end{array}$ & 10.08 & 1143.22 & 1531.40 \\
$\begin{array}{l}\text { Agaricus } \\
\text { bisporus } \\
\text { (kültür) }\end{array}$ & 167.76 & 1630.08 & 256.20 \\
$\begin{array}{l}\text { Agaricus } \\
\text { bisporus } \\
\text { (doğal) }\end{array}$ & 101.28 & 1009.93 & 363.60 \\
\hline
\end{tabular}

\section{Sonuç ve Öneriler}

Yaptığımız çalışmada doğal ortamdan toplanan ve kültür ortamında yetiştirilen Agaricus bisporus ve Pleurotus ostreatus mantarlarının yağ asidi bileşimi ve yüzdesi tespit edilmiş, bu yağ asitlerinin karbon zinciri uzunlukları 14-24 arasında olduğu bulunmuştur (Çizelge 1). Örneklerin analizleri sonucunda, ekstraksiyonun hazırlanması ve metilasyonu işlemi sırasında uygulanan sıcaklık sonucu yağ asitlerinin yıkımı ve kaybı gibi sebeplerden dolayı, kısa zincirli yağ asitleri tespit edilememiştir. Oda sıcaklığında sıvı olan kısa zincirli yağ asitlerinin yüksek sıcaklıkta kolayca buharlaştığı bildirilmiştir (Woldegiorgis ve ark., 2015).
Yapılan çalışmalar sonucunda örneklerde en fazla oranda tespit edilen yağ asitlerinin linoleik, palmitik, stearik ve oleik asit olduğu bulunmuştur. Pleurotus ostreatus türünün kültür formunda linoleik asit (C18:2) \%40.35, palmitik asit (C16:0) \%21.09, oleik asit (C18:1) \%17.90 oranında iken, doğadan toplanan örneklerinde linoleik asit (C18:2) \%40.31, palmitik asit (C16:0) \%20.54, stearik asit (C18:0) \%16.05 oranında olduğu tespit edilmiştir. Agaricus bisporus türünün kültür formunda linoleik asit (C18:2) \%54.44, palmitik asit (C16:0) \%18.45, stearik asit (C18:0) \%14.71, doğadan toplanan örneklerde ise linoleik asit (C18:2) \%49.75, palmitik asit (C16:0) \%20.97, stearik asit (C18:0) \%11.61 olarak tespit edilmiştir. Linoleik asit tüm örneklerde en fazla oranda tespit edilen yağ asidi çeşidi olmuştur. Oranı yüksek olan diğer yağ asitleri sırasıyla palmitik asit (C16:0), stearik asit (C18:0), oleik asit (C18:1) şeklindedir (Çizelge 1). Benzer sonuçlar Yılmaz ve ark. (2006), Ergönül ve ark. (2013), Goyal ve ark. (2015), Woldegiorgis ve ark. (2015), Doğan (2016), Ganesh ve Rajashekhar. (2017) tarafından tespit edilmiştir.

Bu dört çeşit yağ asidinden başka 8 çeşit yağ asidi (miristik asit, pentadekanoik asit, palmitoleik asit, margarik asit, stearik asit, eikosenoik asit, behenik asit, nervonik asit) değişik oranlarda tespit edilmiştir (Çizelge 1). Margarik asit (C17:0), eikosenoik asit (C20:1) ve behenik asit (C22:0) sadece doğal Agaricus bisporus örneklerinde tespit edilmiştir. Eikosenoik asit (C20:1) ve behenik asit (C22:0) Pleurotus ostreatus'un hem doğal ortamdan toplanan örneklerinde hem de kültür formunda tespit edilememiştir. Diğer yağ asitleri farklı oranlarda tespit edilmiştir. Korkmaz ve Kırbağ (2014), tarımsal ve endüstriyel atıklar üzerinde kültürü yapılarak elde ettikleri Pleurotus ostreatus'ta palmitik asit (C16:0), stearik asit (C18:0), oleik asit (C18:1), linoleik asit (C18:2), dokosadienoik asit (C22:2)'i farklı oranlarda tespit etmişlerdir.

Çizelge 2'de çalışılan örneklerdeki toplam doymuş, tekli doymamış ve çoklu doymamış yağ asitlerinin miktarları, Şekil 1, 2 ve 3 'de ise yüzde oranları gösterilmiştir. Buna göre tüm örneklerde doymamış yağ asidi oranının, doymuş yağ asitlerinden daha fazla olduğu görülmektedir. Tespit ettiğimiz bu sonuç Woldegiorgis ve ark. (2015), Yılmaz ve ark. (2006), Barros ve ark. (2008), Korkmaz ve Kırbağ (2014), Goyal ve ark. (2015), (V ve ark., 2017), Doğan (2016) ile tutarlıdır.

Toplam doymamış yağ asidi miktarı en fazla 64.44\% ile doğal ortamdan toplanan Pleurotus ostreatus'da tespit edilmiştir (Çizelge 2, Şekil 1). Doymuş yağ asitlerinin tekli doymamış yağ asitleri ile yer değiştirmesi, yüksek yoğunluklu lipoprotein 
kolesterolü düzeyini arttırır ve düşük dansiteli lipoprotein kolesterolü azaltır. Bu durum arteriyoskleroz riskini artırır (Woldegiorgis ve ark., 2015; Yılmaz ve ark. 2006). Yüksek oranda oleik asit (C18:1) ve linoleik asit (C18:2) bulunduran yağlar, insan sağlığı için çok önemlidir. İnsanlar tarafından üretilmeyen bu yağ asitleri normal büyüme ve gelişme için gereklidir (Goyal ve ark., 2015; Ganesh ve ark., 2017). Doymuş yağ asitlerinden olan palmitik asit araştırma örneklerimizin tümünde tespit edilmiştir. Diğer uzun zincirli yağ asitlerinin birincil olarak sentezinde kullanılan palmitik asit, bitkilerde ve hayvanlarda en yaygın olarak bulunan doymuş yağ asididir (Doğan, 2016). Mantarlarda tespit edilen yağ asitleri cis- yapısında olup, transyağ asitleri rapor edilmemiştir (Woldegiorgis ve ark., 2015).

Türkiye'de yapılan çalışmalarda bu mantarların sahip oldukları bazı element seviyeleri yaygın olarak bildirilirken, vitamin içerikleri ve total protein seviyeleri hakkında yeterince bilgi verilmemiş olduğu görülmüştür. Çalışmamız sayesinde bu mantar türlerinin her iki ortamdan toplanmış örneklerini karşılaştırarak literatür verilerine katkı sağlayacağı düşünülmektedir.

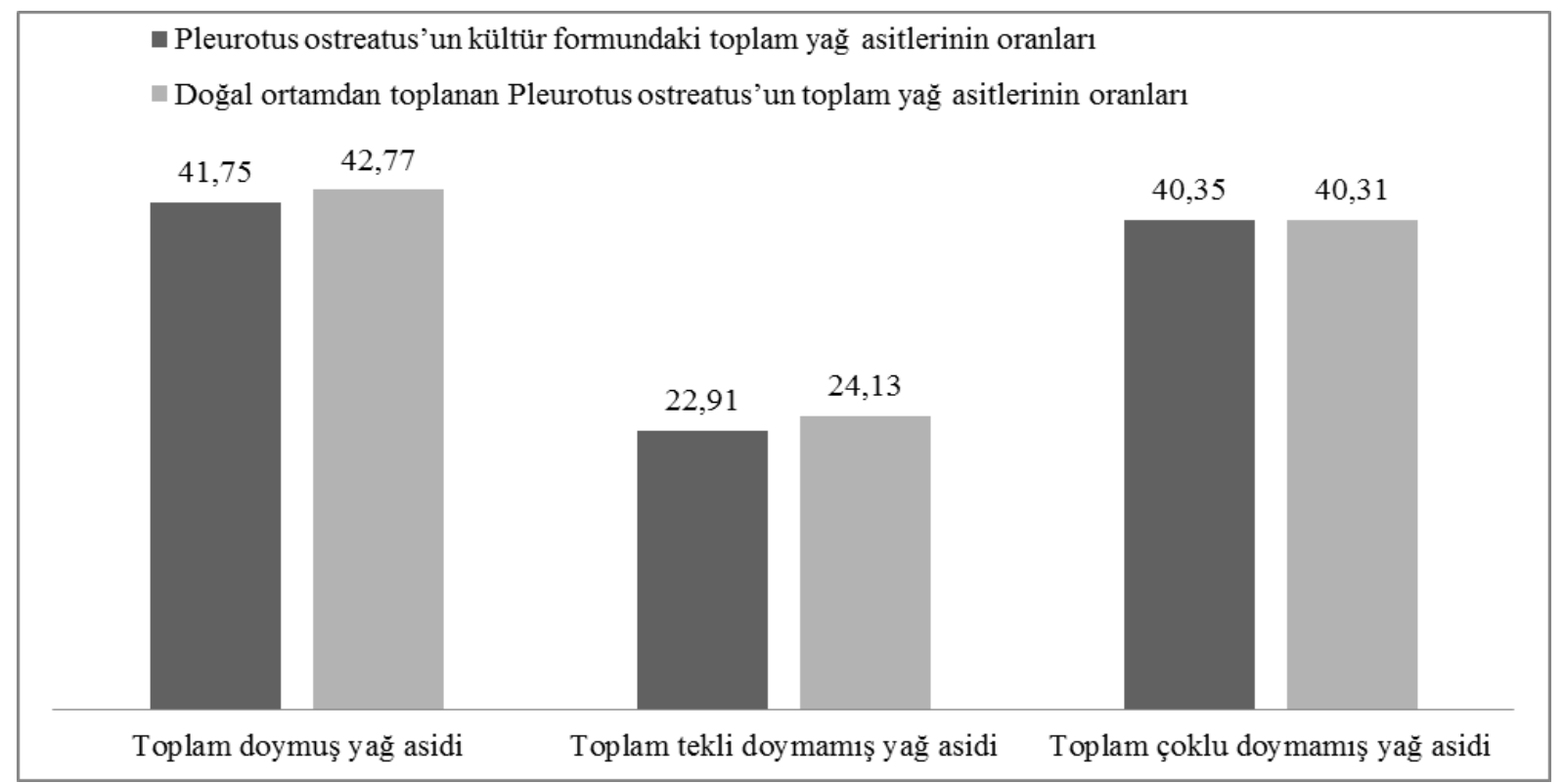

Şekil 1. Pleurotus ostreatus örneklerinde tespit edilen toplam yağ asitlerinin yüzde oranları.

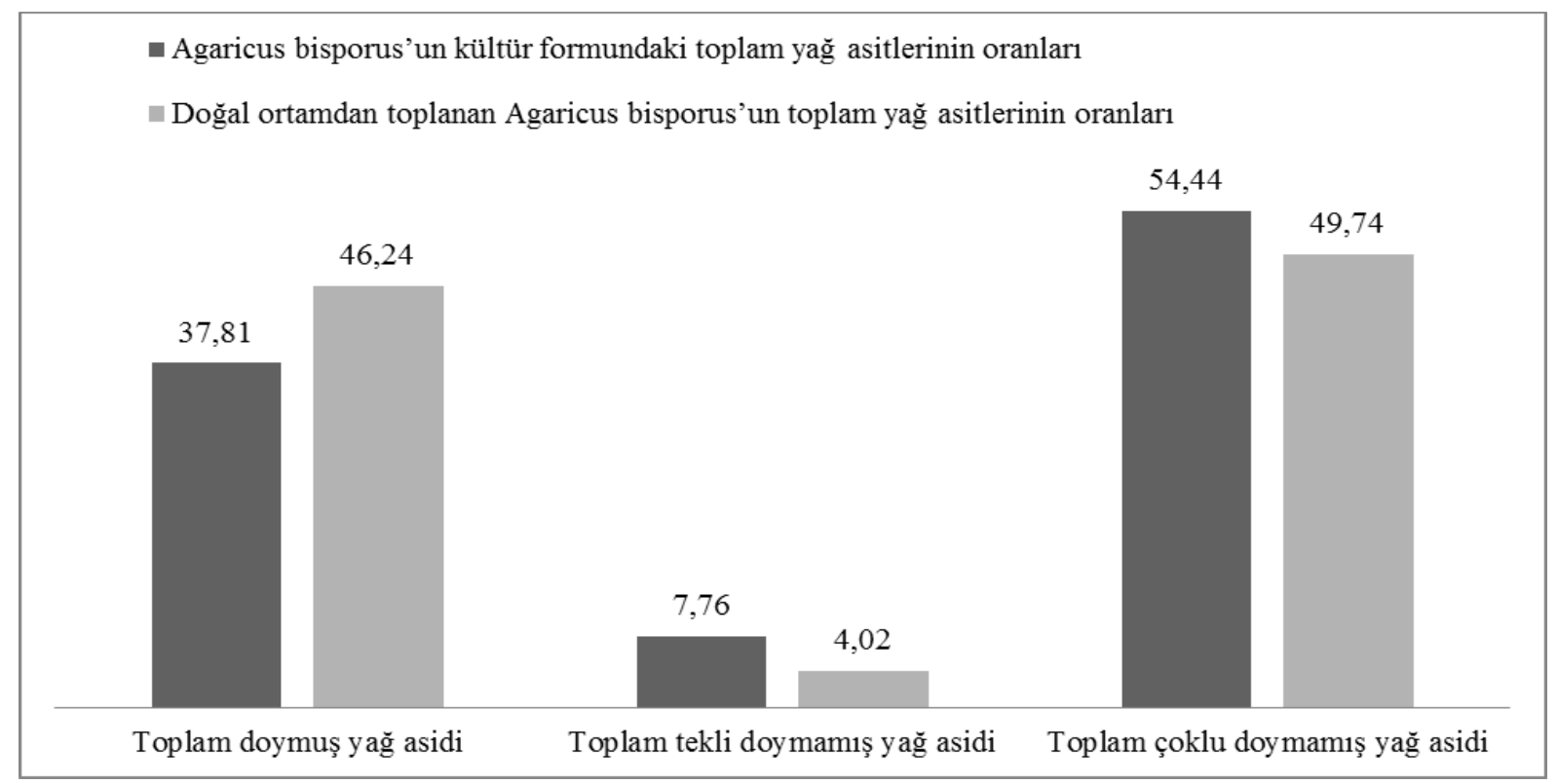

Şekil 2. Agaricus bisporus örneklerinde tespit edilen toplam yağ asitlerinin yüzde oranları. 


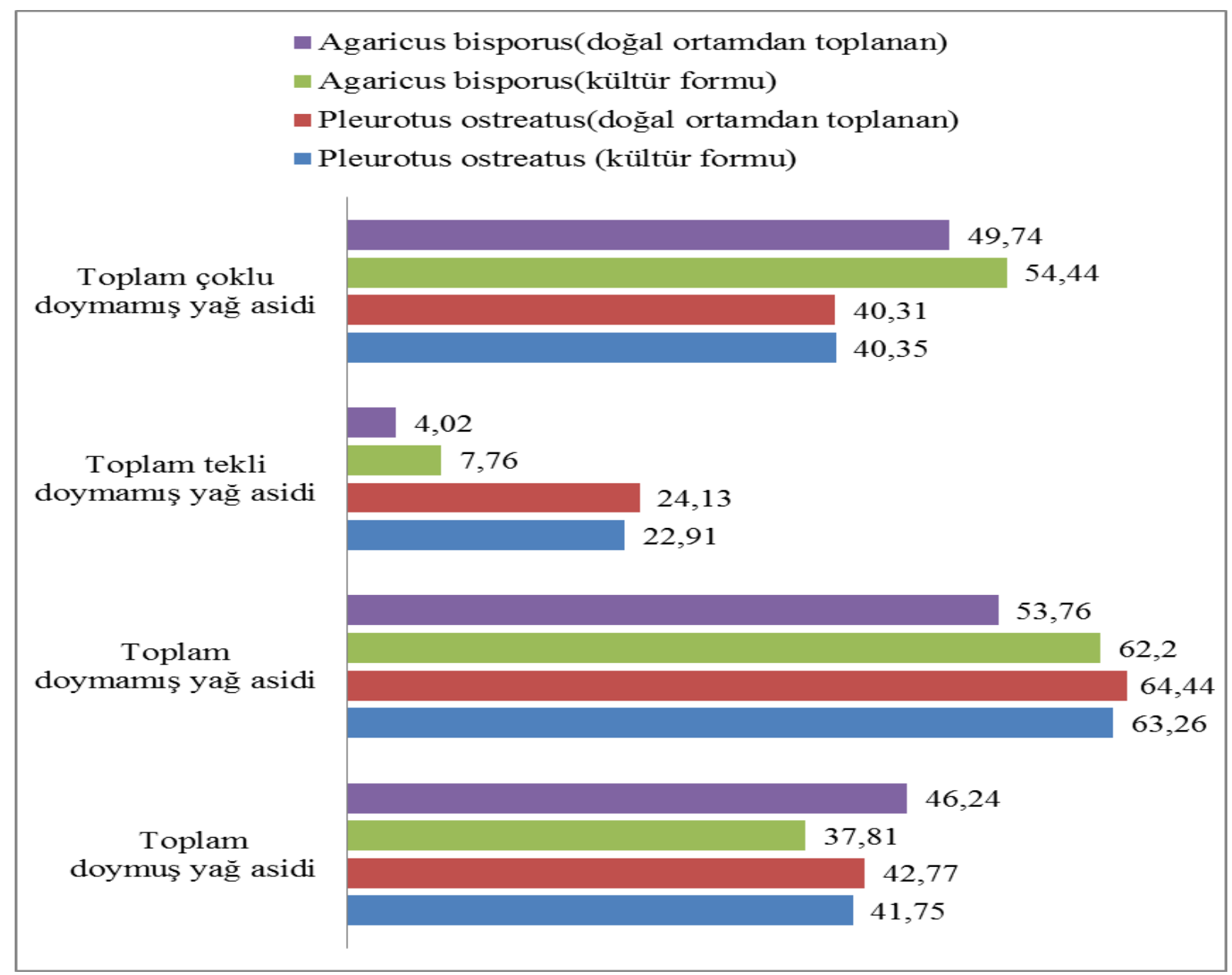

Şekil 3. Agaricus bisporus ve Pleurotus ostreatus örneklerinde tespit edilen toplam yağ asitlerinin yüzde oranları.

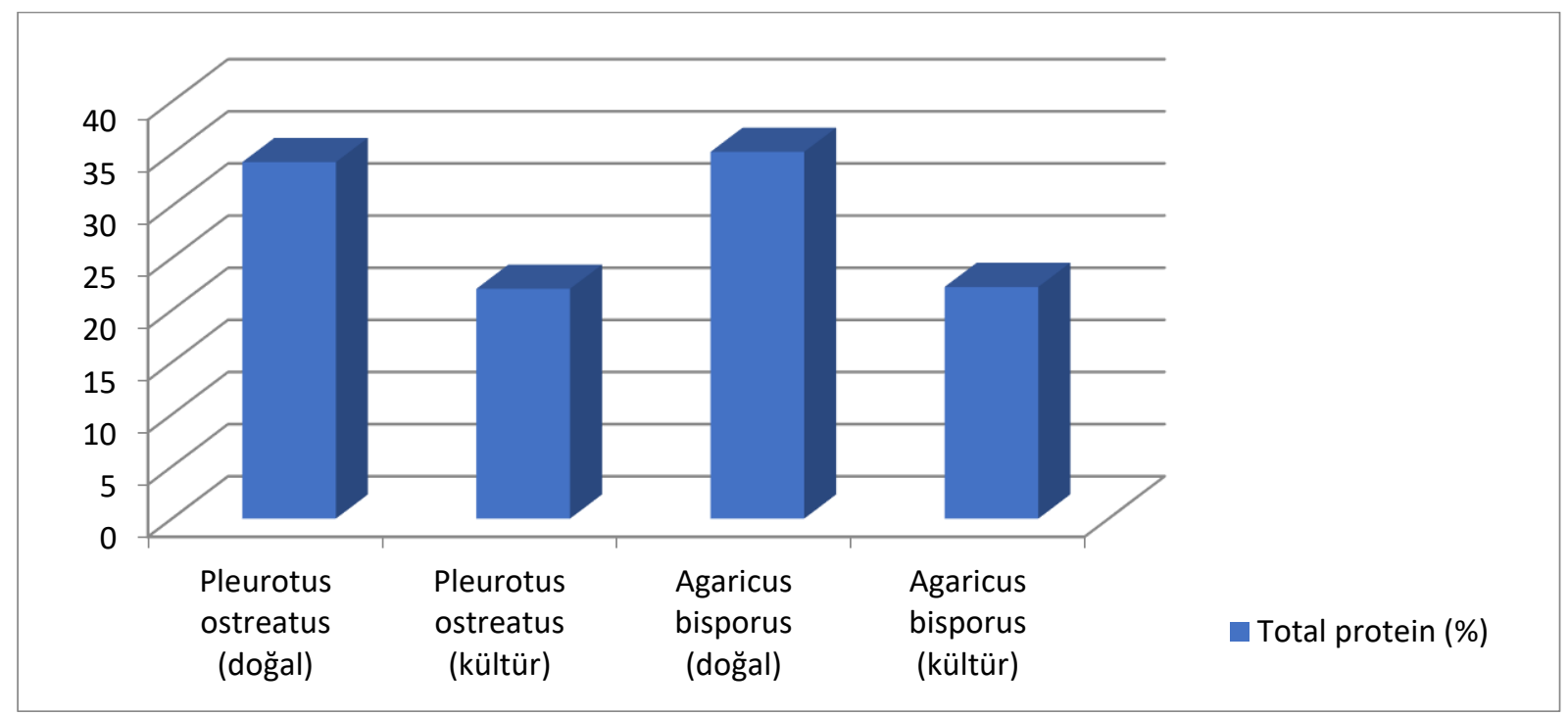

Şekil 4. Agaricus bisporus ve Pleurotus ostreatus örneklerinde tespit edilen total protein yüzde oranları. 


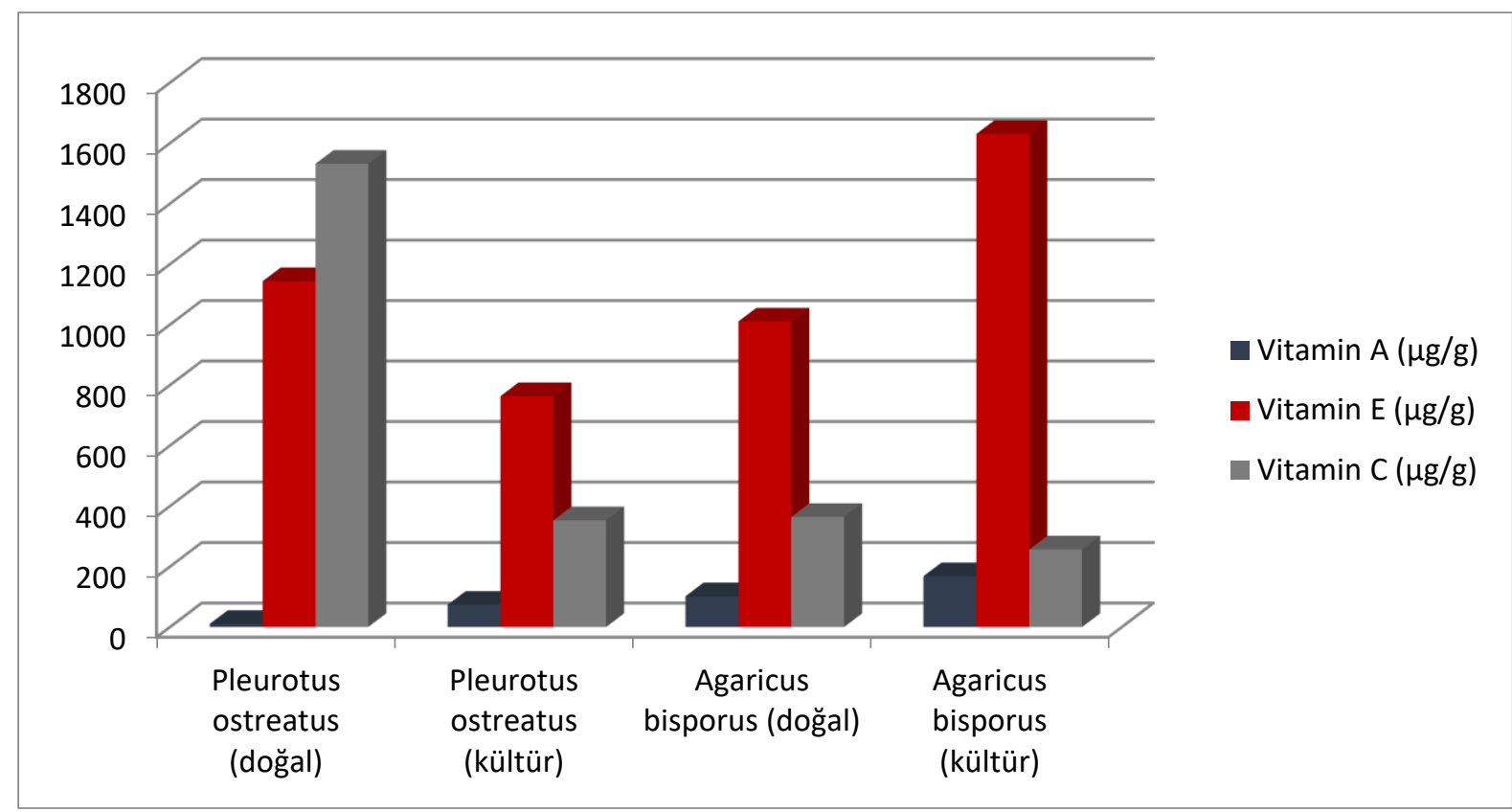

Şekil 5. Agaricus bisporus ve Pleurotus ostreatus örneklerinde tespit edilen vitamin çeşit ve miktarları ( $\mu \mathrm{g} / \mathrm{g})$.

\section{Teşekkür}

Makalemize konu olan mantarların temini ve teşhisinde görev alan Gaziosmanpaşa Üniversitesi Biyoloji bölümüne ve analizlerin yapıldığı Bingöl Üniversitesi Merkezi Araştırma Laboratuvarı çalışanlarına teşekkürü bir borç biliriz.

Not: Bu çalışmanın vitamin kısmı aynı yazar grubu tarafından 19-23 Haziran Ecology 2018 International Symposium/Kastamonu/TURKEY de sözlü özet bildiri olarak sunulmuştur.

\section{Kaynaklar}

Alayunt, N.Ö., Çelik, S., Koparır, M., Karatepe, M. 2015. The effects of 5,5'-Butane-1,4Diylbis[4-Allyl-2-(\{4-[3-

(Trifluoromethyl)Phenyl]Piperazin-1-

YI\}Methyl)-2,4-Dihydro-3h-1,2,4-Triazole-3-

Thione] compound on MDA level and vitamins in serum, liver and kidney of rats. NWSA-Physical Sciences, 10(2): 14-20.

Barros, L., Cruz, T., Baptista, P., Estevinho, L.M., Ferreira, I.C.F.R. 2008. Wild and commercial mushrooms as source of nutrients and nutraceuticals. Food and Chemical Toxicology, 46: 2742-2747.

Christie, W.W. 1990. Gas Chromatography and Lipids. The Oil Press: Glasgow, Scotland.

Çağlarırmak, N. 2011. Edible Mushrooms: An Alternative Food Item. 7th International Conference on Mushroom Biology and Mushroom Products, 548-554 page, France.

Çöteli, E., Karataş, F. 2015. The investigatıon of water-soluble vitamin amounts in edible some mushroom species. EÜFBED - Fen Bilimleri Enstitüsü Dergisi, 8(2): 213-222.

Doğan, H.H. 2016. Fatty acid compositions of two mushrooms in Turkey. International Journal of Recent Scientific Research, 7(4): 1001710020.

Eren, E., Pekşen, A. 2016. Türkiye'de kültür mantarı sektörünün durumu ve geleceğine bakış. Türk Tarım-Gıda Bilim ve Teknoloji Dergisi, 4(3): 189-196.

Ergönül, P.G., Akata, I., Kalyoncu, F., Ergönül, B. 2013. Fatty Acid Compositions of Six Wild Edible Mushroom Species. The Scientific World Journal, 1-4.

Ganesh, V.R., Rajashekhar, S.M. 2017. Compositional and nutritional studies on two wild mushrooms from Western Ghat forests of Karnataka, India. International Food Research Journal, 24(2): 679-684.

Goyal, R., Grewal, R.B., Goyal, R.K. 2015. Fatty acid composition and dietary fibre constituents of mushrooms of North India. Emirates Journal of Food and Agriculture, 27(12): 927-930.

Hara, A., Radin, N.S. 1978. Lipid extraction of tissues with a low-toxicity solvent. Analytical Biochemistry, 90: 420-426.

Hawksworth, D.L. 2001. The magnitude of fungal diversity: the 1.5 million species estimate revisited, Mycological Research, 105(12): 1422-1432.

Hawksworth, D.L., Kirk, P.M., Sutton, B.C., Pegler, D.N. 1996. Ainsworth and Bisby's Dictionary of the Fungi, 8th edition. CAB International, Wallingford, United Kingdom. 
Kibar, B. 2015. Iğdır ili mantar tüketim alışkanlıklarının belirlenmesi. Iğdır Üni. Fen Bilimleri Enst. Der., 5(4): 9-16.

Kirk, P. 2011. Index Fungorum. URL: http://www.indexfungorum.org (Erişim tarihi: 04 Ocak 2018).

Korkmaz, V., Kırbağ, S. 2014. Tarımsal ve Endüstriyel atıklar üzerinde kültürü yapılan Pleurotus taksonlarının yağ asidi düzeylerinin tespit edilmesi. BEÜ Fen Bilimleri Dergisi, 3(2): 162167.

Pekşen, A. 2013. Mantarların insan hayatı ve sağlığındaki yeri. Bahçe Haber, 2(1): 10-15.

Turfan, N., Pekşen, A., Kibar, B., Ünal, S., 2018. Determination of nutritional and bioactive properties in some selected wild growing and cultivated mushrooms from Turkey. Acta Scientiarum Polonurum Hortorum Cultus., 17(3): 57-72.
Woldegiorgis, A.Z., Abate, D., Haki, G.D., Ziegler, G.R., Harvatine, K.J. 2015. Fatty acid profile of wild and cultivated edible mushrooms collected from Ethiopia. Journal of Nutrition \& Food Sciences, 5(3): 360.

Yılmaz, N., Solmaz, M., Türkekul, İ., Elmastaş, M. 2006. Fatty acid composition in some wild edible mushrooms growing in the middle Black Sea region of Turkey. Food Chemistry, 99: 168-174.

Yılmaz, Ç.H., Bengü, A.S. 2018. The investigation of fatty acids and mineral profiles of some edible Lactarius species ( $L$. deliciosus, $L$. deterrimus). Biological Diversity and Conservation, 11(1): 95-104.

Zhang, Y., Geng, W., Shen, Y., Wang, Y., Dai, Y.C. 2014. Edible Mushroom cultivation for food security and rural development in China: Bioinnovation, technological dissemination and marketing. Sustainability, 6: 2961-2973. 